\title{
Voice Recognition Untuk Otomatisasi Sistem Pengakses Pintu
}

${ }^{1}$ Indah Purwitasari Ihsan, ${ }^{2}$ Sukriyah Buwarda, ${ }^{3}$ Hilda Novianty, ${ }^{4}$ Ifsan Aditya Putra

1,2,3,4 Universitas Fajar Makassar, Indonesia

I'indah.ihsan13@gmail.com; ' sukriyah.warda@gmail.com; 'hildanovianty9@gmail.com; ' 1 ifsanputra@gmail.com;

\begin{tabular}{l} 
Article Info \\
\hline Article history: \\
Received, 07-01-2021 \\
Revised, 25-01-2021 \\
Accepted, 29-01-2021 \\
\hline Kata Kunci: \\
Pengunci Pintu \\
Biometrik Suara \\
Voice recognition \\
Solenoid lock door \\
\hline \hline
\end{tabular}

Keywords:

Door lock

voice biometrics

voice recognition

solenoid lock door

\begin{abstract}
ABSTRAK
Penggunaan kunci manual sebagai pembuka dan pengunci pintu masih belum optimal. Masalah yang sering terjadi adalah pemilik kunci sering kali lupa dimana menyimpan kunci bahkan hingga terjadi kehilangan kunci. Sistem biometrik pola suara memiliki ciri khas dan karakteristik yang berbeda pada setiap manusia, maka suara dapat dijadikan salah satu alternatif solusi, yaitu suara sebagai kunci untuk membuka pintu secara otomatis sehingga lebih efisien. Otomatisasi sistem pengunci pintu dibuat menggunakan Elechouse v3 yang berfungsi sebagai voice recognition serta Solenoid lock door sebagai pengunci otomatis pada pintu. Hasil pengujian fungsional menggunakan black box menunjukkan bahwa seluruh alat yang dirangkai berfungsi sesuai fungsinya. Pengujian tingkat keberhasilan sistem dilakukan menggunakan variable derau, non derau dan jarak. Pada data training tingkat keberhasilan sistem ini jika tanpa derau adalah $100 \%$, sedangkan dengan derau $50.0 \mathrm{~dB}$ hingga $70 \mathrm{~dB}$ rata-rata tingkat keberhasilannya adalah 56,2\%. Untuk jarak 30 $\mathrm{cm}$ sampai $180 \mathrm{~cm}$ rata-rata keberhasilannya sebesar $40,51 \%$. Jarak terjauh adalah pada jarak $150 \mathrm{~cm}$ dengan presentase keberhasilan 5\%. Pada data testing tingkat keberhasilannya jika tanpa derau adalah $0 \%$, sedangkan dengan derau $50.0 \mathrm{~dB}$ hingga $70 \mathrm{~dB}$ rata-rata tingkat keberhasilannya adalah 1,9\%. Untuk jarak $30 \mathrm{~cm}$ sampai $180 \mathrm{~cm}$ rata-rata keberhasilannya sebesar $0 \%$.
\end{abstract}

\section{ABSTRACT}

The use of manual locks as door openers and locks is still not optimal. The problem that often occurs is that the key owner often forgets where to store the key and even loses the key. The voice pattern biometric system has different characteristics for each human, so sound can be an alternative solution, namely voice as a key to open doors automatically so that it is more efficient. Door lock system automation is made using Elechouse v3 which functions as voice recognition and Solenoid door lock as automatic locking of doors. The results of functional testing using a black box show that all the tools assembled function according to their function. Testing the success rate of the system is carried out using noise, non-noise and distance variables. In the training data, the success rate of this system without noise is $100 \%$, while with a noise of $50.0 \mathrm{~dB}$ to $70 \mathrm{~dB}$ the average success rate is $56.2 \%$. For a distance of $30 \mathrm{~cm}$ to $180 \mathrm{~cm}$ the success rate is $40.51 \%$. The farthest distance is at a distance of 150 $\mathrm{cm}$ with a success percentage of $5 \%$. In the testing data, the success rate without noise is $0 \%$, while with a noise of $50.0 \mathrm{~dB}$ to $70 \mathrm{~dB}$ the average success rate is $1.9 \%$. For a distance of $30 \mathrm{~cm}$ to $180 \mathrm{~cm}$ the success rate is $0 \%$.

This is an open access article under the CC BY-SAlicense.

\section{Penulis Korespondensi:}

Indah Purwitasari Ihsan, Program Studi Teknik Elektro, Universitas Fajar,

Email: indah.ihsan13@gmail.com

\section{PENDAHULUAN}

Ketepatan, efisiensi, dan efektivitas adalah hal yang terpenting dalam menjalankan aktifitas sehari-hari. Karena itu berbagai macam pengembangan dalam bidang teknologi dirancang untuk memberikan kenyamanan dan kemudahan. Salah satu kemudahan yang diharapkan adalah kemudahan dalam mengakses pintu rumah maupun pintu kantor secara otomatis tanpa harus 
membawa kunci. Perkembangan teknologi pengunci dan pembuka pintu sudah dipermudah dengan menggunakan perangkat seperti kunci, PIN serta RFID, namun perangkat-perangkat tersebut masih berbentuk fisik dan mengharuskan penggunanya untuk membawanya kemanapun, sehingga kurang efisien. Selain itu saat ini masih banyak yang menggunakan kunci manual yang efektifitasnya masih belum optimal. Masalah yang sering terjadi yaitu pengguna kunci yang membawa barang yang berlebihan akan sulit untuk mengambil kunci untuk membuka pintu. Pemilik rumah yang biasanya membawa banyak kunci ketika berpergian sering kali lupa bahkan kehilangan kunci. Maka dibutuhkanlah sebuah sistem pengunci dan pembuka pintu otomatis yang memudahkan pemilik rumah untuk dapat mengakses pintu dan mengunci pintunya tanpa harus membawa kunci maupun perangkat apapun.

Biometrik adalah karakteristik yang terukur. Dalam dunia teknologi, biometrik digunakan untuk menganalisis fisik dan kelakuan manusia[1]. Suara manusia merupakan fenomena fisik yang memiliki perbedaan pada setiap orang[2], [3]. Penelitian ini memanfaatkan biometrik pola suara yang memiliki karakteristik berbeda pada setiap manusia dimana perbedaan ini dijadikan sebagai kunci untuk membuka pintu secara otomatis sehingga lebih efisien. Voice recognition merupakan salah satu teknik yang memungkinkan computer untuk dapat mengenali pola suara[4], [5],[6]. Metode pembelajaran pada sistem voice recognition untuk fitur ekstraksi (feature extraction) dan fitur pencocokan (feature matching) [7], [8] pada pengenalan pola suara memberi solusi pada masalah tersebut diatas.

Penelitian sebelumnya yang dilakukan oleh Sinta Ariyanti, Slamet Seno Adi dan Sugeng Purbawanto, "sistem buka tutup pintu secara otomatis dengan menggunakan pengenalan suara", pada tahun 2018, menggunakan dua kata yang digunakan untuk mengkodekan yaitu kata "buka" dan "tutup". Keberhasilan pemberian perintah pada alat pengujian oleh orang yang berwenang adalah 95\% untuk kata "buka" dan 90\% untuk kata "tutup"[9]. Penelitian selanjutnya oleh Ashar Seppiawan, Nurussa'adah, Ponco Siwindarto, merealisasikan sebuah perangkat kunci yang berbasis mikrokontroler yang mampu membaca sinyal masukan suara dan menyimpannya dalam sebuah modul yaitu easyVR. Cukup dengan mengatakan password maka pintu akan terbuka secara otomatis. Dari pengujian dengan modul easyVR diuji dari beberapa orang yang berbeda didapatkan tingkat keberhasilan yang cukup rendah dengan presentase $10,4 \%$. Dari pengujian tersebut maka dapat disimpulkan bahwa modul sensor easyVR kurang baik dalam menangkap suara yang diberikan dari orang yang berbeda[10]. Penelitian lainnya yang dilakukan oleh A.Asni B, Aswadul Fitri, dan Muzakky Mursyid, pada tahun 2017 menggunakan modul easyVR yang diprogram melalui modul arduino uno, sehingga dapat membuat password dalam bentuk suara. Tingkat keberhasilan alat ini adalah $90 \%$ dengan delay 2 detik oleh orang yang sama antara yang suaranya direkam dan disimpan pada modul easyVR dengan memberikan perintah. Sedangkan, untuk orang yang berbeda keberhasilan alat ini hanya 8,5\%[11].

Pada penelitian ini voice recognition digunakan sebagai pengganti kunci untuk membuka pintu secara otomatis menggunakan tools Elechouse v3 sebagai alat untuk menyimpan rekaman suara dan mencocokkan suara hasil rekaman tersebut pada database. Solenoid lock door digunakan untuk membuka pintu secara otomatis apabila suara dikenali oleh modul elechouse, seluruh alat yang dirangkai dikendalikan oleh arduino uno sebagai mikrokontroler utama. Kata kunci yang digunakan adalah "open". Pengujian akan dilakukan dengan menguji fungsionalitas sistem menggunakan black box dan pengujian akurasi menggunakan variabel derau, non-derau, dan jarak. Dengan adanya otomatisasi sistem ini diharapkan dapat memudahkan pemilik rumah untuk dapat membuka dan mengunci pintu tanpa harus membawa kunci maupun perangkat apapun.

\section{METODE PENELITIAN}

Sistem akan dikembangkan menggunakan metode pengembangan sistem waterfall yang dalam pengembangan software dimana proses pengerjaannya harus dilakukan secara berurutan[12], meliputi analisis kebutuhan sistem, perancangan dan desain sistem, pembuatan sistem dengan mengimplementasikan rancangan dan desain yang telah dibuat sebelumnya, mengintegrasikan perangkat lunak dan perangkat keras, pengujian fungsionalitas sistem, pengujian akurasi, terakhir akan dilakukan perbaikan atas temuan kesalahan yang terjadi. Alat dan bahan yang digunakan dalam penelitian ini yaitu, Sketch_oct10b, Arduino IDE, Bahasa Pemrograman C++, Library Elechouse V3, 
JSAI : Journal Scientific and Applied Informatics

Vol. 4, No. 01, Januari 2021, hal. 116 125

E-ISSN: 2614-3054; P-ISSN: 2614-3062, accredited by Kemenristekdikti, Sinta 5

DOI: 10.36085

Elechouse V3, Arduino Uno, Relay, Kabel Jumper, dan Solenoid Lock Door. Teknik pengumpulan data menggunakan teknik kajian pustaka sebagai bahan referensi. Teknik pengumpulan data dengan teknik observasi dan pengamatan secara langsung terhadap kinerja dan fungsionalitas sistem yang dirangkai. Tahapan yang dilakukan pada penelitan ini digambarkan pada gambar 1 berikut :

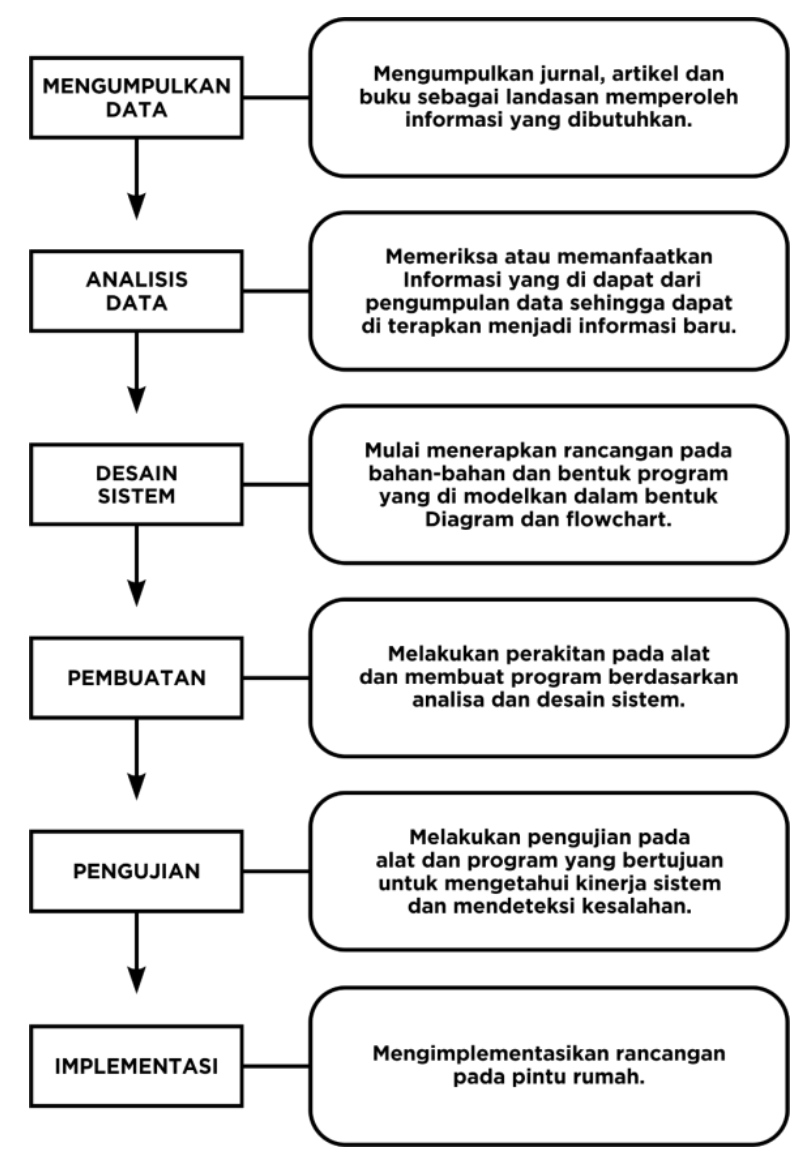

Gambar 1. Bagan Tahapan Penelitian

\section{Perancangan Rangkaian Sistem}

Perancangan rangkaian alat dapat dilihat pada gambar 2 berikut :

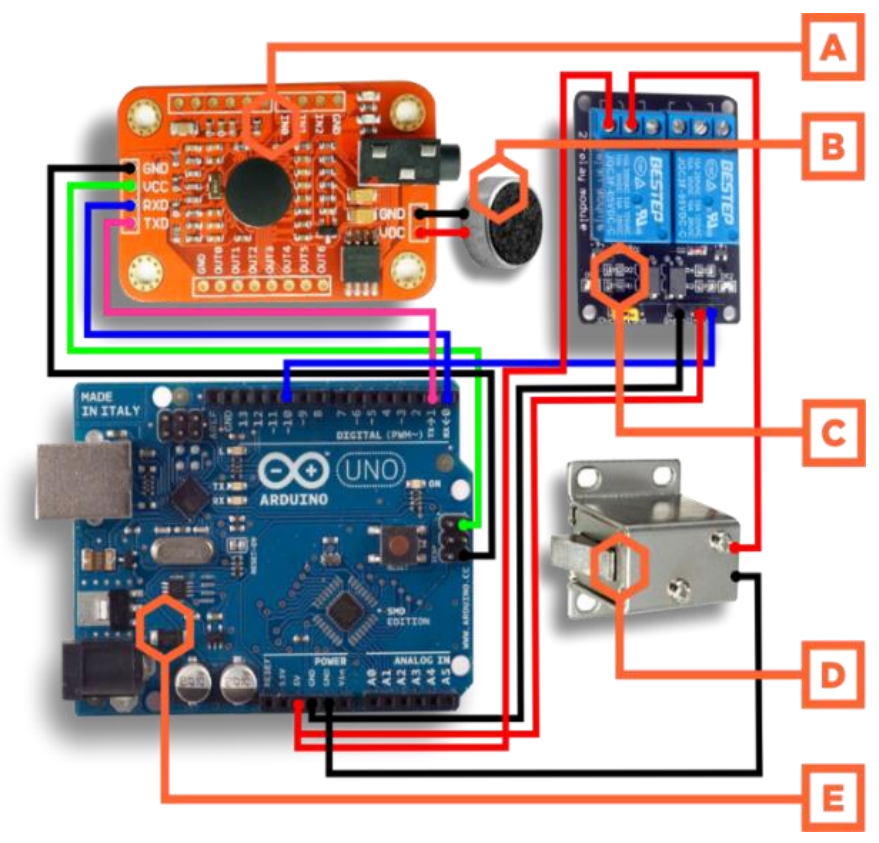

Gambar 2. Perancangan Rangkaian Sistem (Dokumentasi Pribadi) 
Keterangan :

A. Mikrofon berfungsi untuk menangkap suara yang dihubungkan pada modul elechouse v3.

B. Elechouse v3 sebagai tools voice recognition yang berfungsi untuk pencocokan suara dan mengubah sinyal suara menjadi data digital yang dihubungkan pada Arduino uno.

C. Arduino uno berfungsi sebagai microcontroller

D. Modul relay berfungsi menjalankan perintah dari Arduino dan menjaga tegangan solenoid lock door tetap stabil.

E. Solenoid lock door berfungsi untuk mekanikal pembuka dan pengunci.

\section{Perancangan Prototipe}

Sebelum sistem diterapkan pada pintu yang sebenarnya, terlebih dahulu dibuat prototype rancangan prototipe dapat dilihat pada gambar 3 berikut :

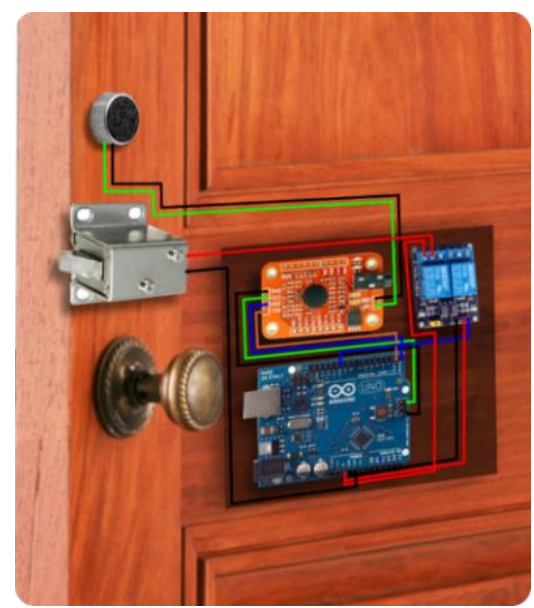

Gambar 3. Rancangan Prorotipe (Dokumentasi Pribadi)

\section{Flowchart Sistem}

Flowchart sistem ditunjukkan pada gambar 4 berikut :

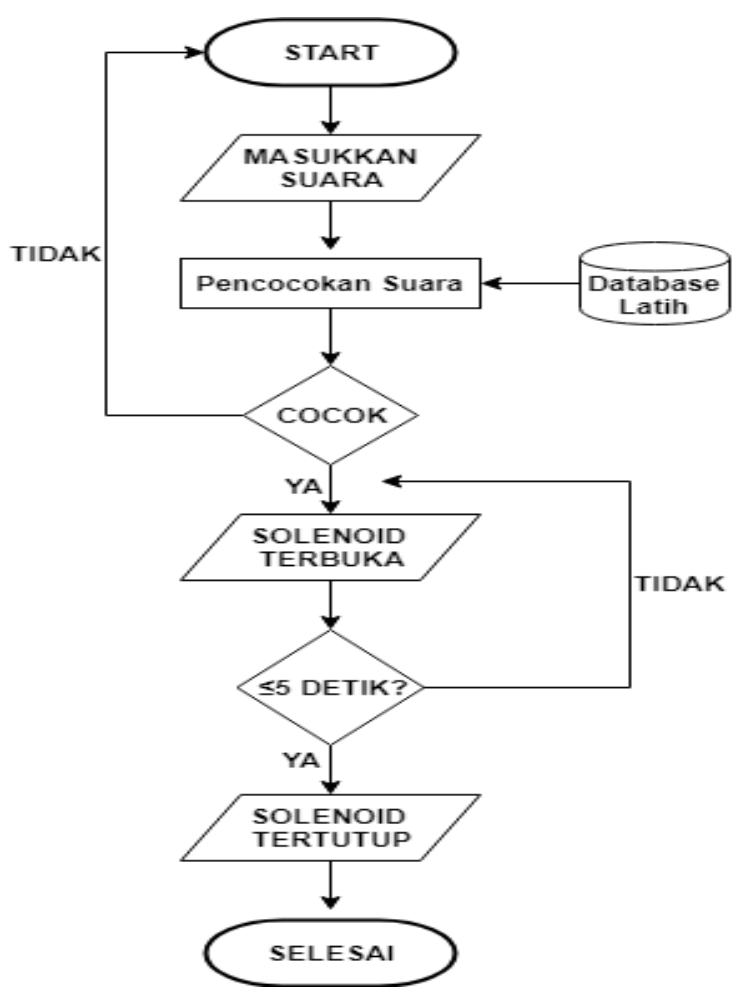

Gambar 4. Flowchart Sistem 
JSAI : Journal Scientific and Applied Informatics

Vol. 4, No. 01, Januari 2021, hal. 116 125

E-ISSN: 2614-3054; P-ISSN: 2614-3062, accredited by Kemenristekdikti, Sinta 5

DOI: 10.36085

\section{HASIL DAN ANALISIS}

\subsection{Prototipe Sistem}

Prorotipe merupakan implementasi awal dari rancangan sistem yang dibuat untuk mendemonstrasikan konsep-konsep dan percobaan[13]. Gambar 5 berikut merupakan gambar prototipe dari rangkaian alat otomatiasi sistem pengunci pintu:

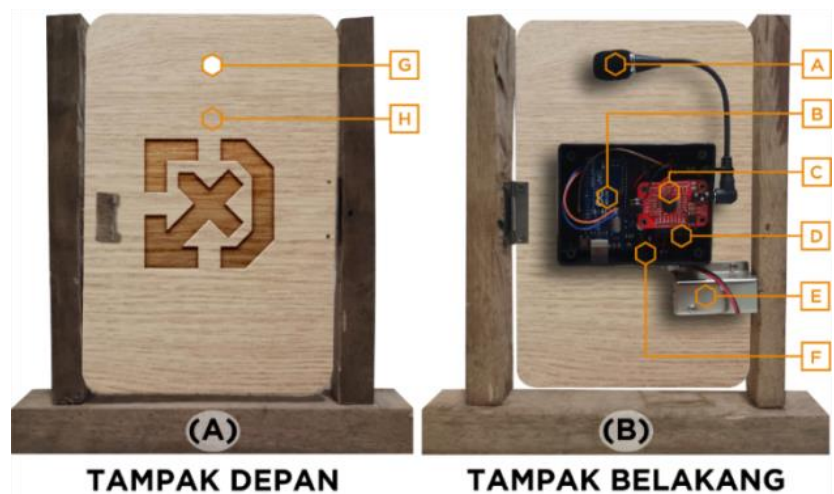

Gambar 5. Prototipe Sistem (Dokumentasi Pribadi)

Keterangan :

A. Mikrofon berfungsi untuk menangkap suara.

B. Arduino berfungsi sebagai mikrokontroler.

C. Elechouse V3 berfungsi sebagai voice recognition.

D. Relay berfungsi sebagai saklar yang menghubungkan indikator.

E. Solenoid sebagai penggerak kunci otomatis pada pintu.

F. Power berfungsi untuk memberikan daya $(12 \mathrm{~V})$ pada Arduino dan solenoid lock door.

G. Lubang mic (mikrofon) berfungsi untuk menerima suara agar lebih jernih dan jelas.

H. Pintu

\subsection{Pengujian Fungsionalitas}

Pengujian Fungsionalitas terhadap alat yang telah dibangun dilakukan menggunakan teknik pengujian black box. Pengujian ini bertujuan untuk memastikan bahwa masing-masing alat yang telah dirangkai bekerja sesuai dengan tujuan yang telah didefinisikan sebelumnya[14]. Pengujian dilakukan oleh 5 responden. Hasil pengujian black box dapat dilihat pada tabel 1 berikut :

Tabel 1. Hasil Pengujian Fungsionalitas

\begin{tabular}{|c|c|c|c|c|c|c|c|c|c|c|c|c|}
\hline \multirow{3}{*}{ No } & \multirow{3}{*}{$\begin{array}{c}\text { Alat dan } \\
\text { Bahan }\end{array}$} & \multirow{3}{*}{$\begin{array}{l}\text { Aktifitas } \\
\text { Pengujian }\end{array}$} & \multicolumn{10}{|c|}{ Responden } \\
\hline & & & \multicolumn{2}{|c|}{1} & \multicolumn{2}{|c|}{2} & \multicolumn{2}{|c|}{3} & \multicolumn{2}{|c|}{4} & \multicolumn{2}{|c|}{5} \\
\hline & & & $\mathrm{B}$ & $\mathrm{T}$ & $\mathrm{B}$ & $\mathrm{T}$ & $\mathrm{B}$ & $\mathrm{T}$ & $\mathrm{B}$ & $\mathrm{T}$ & $\mathrm{B}$ & $\mathrm{T}$ \\
\hline 1 & Microphone & Menerima Suara & 1 & 0 & 1 & 0 & 1 & 0 & 1 & 0 & 1 & 0 \\
\hline 2 & Arduino & $\begin{array}{l}\text { Mengontrol dan } \\
\text { mengintegrasikan } \\
\text { seluruh } \\
\text { rangkaian alat }\end{array}$ & 1 & 0 & 1 & 0 & 1 & 0 & 1 & 0 & 1 & 0 \\
\hline \multirow[t]{2}{*}{3} & \multirow[t]{2}{*}{$\begin{array}{l}\text { Elechouse } \\
\text { V3 }\end{array}$} & $\begin{array}{l}\text { Menyimpan } \\
\text { suara ke dalam } \\
\text { database }\end{array}$ & 1 & 0 & 1 & 0 & 1 & 0 & 1 & 0 & 1 & 0 \\
\hline & & $\begin{array}{l}\text { Mengenali pola } \\
\text { suara }\end{array}$ & 1 & 0 & 1 & 0 & 1 & 0 & 1 & 0 & 1 & 0 \\
\hline 4 & Relay & On atau off & 1 & 0 & 1 & 0 & 1 & 0 & 1 & 0 & 1 & 0 \\
\hline 5 & $\begin{array}{l}\text { Selenoid } \\
\text { Lock Door }\end{array}$ & $\begin{array}{l}\text { Mengunci pintu } \\
\text { secara otomatis }\end{array}$ & 1 & 0 & 1 & 0 & 1 & 0 & 1 & 0 & 1 & 0 \\
\hline \multicolumn{3}{|c|}{ Total } & 5 & 0 & 5 & 0 & 5 & 0 & 5 & 0 & 5 & 0 \\
\hline
\end{tabular}


JSAI : Journal Scientific and Applied Informatics

Vol. 4, No. 01, Januari 2021, hal. 116 125

E-ISSN: 2614-3054; P-ISSN: 2614-3062, accredited by Kemenristekdikti, Sinta 5

DOI: 10.36085

Keterangan:

$\mathrm{B}=$ Bekerja; $\mathrm{T}=$ Tidak bekerja

Berdasarkan hasil pengujian black box oleh 5 orang responden, menyatakan bahwa semua alat yang diujikan bekerja sesuai fungsinya.

\subsection{Pengujian Tanpa Derau}

Pengujian dilakukan terhadap 14 dataset yang terbagi 7 data training yang tersimpan dalam 1 database suara dan 7 data testing pada jarak $5 \mathrm{~cm}$ dari mikrofon. Pengujian dilakukan tanpa gangguan (derau) yang ada didaerah sekitar pengujian. Hasil pengujian terhadap data training disajikan pada tabel 2 berikut :

Tabel 2 Pengujian Tanpa Derau Terhadap Data Training

\begin{tabular}{|c|c|c|c|c|}
\hline \multirow{3}{*}{$\begin{array}{c}\text { Suara } \\
\text { Penggun } \\
\text { a }\end{array}$} & \multicolumn{3}{|c|}{ Pengujian } & \multirow{3}{*}{$\begin{array}{c}\begin{array}{c}\text { Presentasi } \\
\text { Keberhasil } \\
\text { an }\end{array} \\
\end{array}$} \\
\hline & 1 & 2 & 3 & \\
\hline & 1 & 1 & 1 & \\
\hline Hilda & 1 & 1 & 1 & $100 \%$ \\
\hline Ifsan & 1 & 1 & 1 & $100 \%$ \\
\hline Fadel & 1 & 1 & 1 & $100 \%$ \\
\hline Adel & 1 & 1 & 1 & $100 \%$ \\
\hline Arfan & 1 & 1 & 1 & $100 \%$ \\
\hline Tirta & 1 & 1 & 1 & $100 \%$ \\
\hline Angga & 1 & 1 & 1 & $100 \%$ \\
\hline \multicolumn{4}{|c|}{ Rata - rata keberhasilan } & $100 \%$ \\
\hline
\end{tabular}

Dari hasil pengujian tersebut diketahui bahwa sistem bekerja sangat baik dengan keberhasilan $100 \%$ dalam kondisi suara tanpa derau.

Hasil pengujian terhadap data testing disajikan pada tabel 3 berikut :

Tabel 3 Pengujian Tanpa Derau Terhadap Data Testing

\begin{tabular}{|c|c|c|c|c|}
\hline \multirow{3}{*}{$\begin{array}{c}\text { Suara } \\
\text { Penggun } \\
\text { a }\end{array}$} & \multicolumn{3}{|c|}{ Pengujian } & \multirow{3}{*}{$\begin{array}{c}\text { Presentas } \\
\text { Keberhasi } \\
\text { an }\end{array}$} \\
\hline & 1 & 2 & 3 & \\
\hline & 0 & 0 & 0 & \\
\hline Ismail & 0 & 0 & 0 & $0 \%$ \\
\hline Cyta & 0 & 0 & 0 & $0 \%$ \\
\hline Qila & 0 & 0 & 0 & $0 \%$ \\
\hline Rizaldy & 0 & 0 & 0 & $0 \%$ \\
\hline Rifqy & 0 & 0 & 0 & $0 \%$ \\
\hline Juna & 0 & 0 & 0 & $0 \%$ \\
\hline Dinda & 0 & 0 & 0 & $0 \%$ \\
\hline \multicolumn{4}{|c|}{ Rata - rata keberhasilan } & $0 \%$ \\
\hline
\end{tabular}

Dari hasil pengujian tersebut diketahui bahwa sistem bekerja sangat baik dengan pengertian bahwa dalam kondisi suara tanpa derau sistem berhasil untuk tidak mengenali satupun data testing.

\subsection{Pengujian Dengan Derau}

Derau merupakan noise/sinyal gangguan bersifat suara lain yang tidak diinginkan yang menyebabkan terganggunya proses pengenalan suara[15]. Pengujian dilakukan terhadap 14 dataset yang terbagi atas 7 data training yang tersimpan dalam 1 database suara dan 7 data testing. Pengujian dilakukan dengan memutar derau pink noise.mp3 sebagai derau melalui pengeras suara dengan intensitas suara $55.0 \mathrm{~dB}-65.0 \mathrm{~dB}$ dengan frekuensi $175.0 \mathrm{~Hz}$. Intensitas suara derau dipilih secara random dengan batasan suara pink noise terendah yaitu $0 \mathrm{~dB}$ dan intensitas tertinggi yaitu $100 \mathrm{~dB}$, 
JSAI : Journal Scientific and Applied Informatics

Vol. 4, No. 01, Januari 2021, hal. 116 125

E-ISSN: 2614-3054; P-ISSN: 2614-3062, accredited by Kemenristekdikti, Sinta 5

DOI: 10.36085

maka diambil ambang batas nilai tengah intensitas derau pink noise yaitu dimulai pada intensitas 50 $\mathrm{dB}$.

Hasil pengujian terhadap data training menggunakan derau pink noise pada modul elechouse V3 disajikan pada tabel 4 berikut :

Tabel 4 Pengujian Derau Terhadap Data Training

\begin{tabular}{|c|c|c|c|c|c|c|c|c|c|c|c|c|c|c|c|c|c|c|c|c|}
\hline \multirow{3}{*}{$\begin{array}{l}\text { Suara } \\
\text { Pengeguna }\end{array}$} & \multirow{2}{*}{\multicolumn{3}{|c|}{$\begin{array}{c}\text { PinkNoise:50.0 d8 } \\
\text { Pengajijan }\end{array}$}} & \multirow{3}{*}{$\begin{array}{l}\text { Presentabsi } \\
\text { Keberhasilan }\end{array}$} & \multirow{2}{*}{\multicolumn{3}{|c|}{$\begin{array}{c}\text { Pink Noise 55.0d8 } \\
\text { Penoijizn }\end{array}$}} & \multirow{3}{*}{$\begin{array}{c}\text { Presentasi } \\
\text { Keberhasilan }\end{array}$} & \multirow{2}{*}{\multicolumn{3}{|c|}{$\frac{\text { Pinkloise:60.0dB }}{\text { Pengyjizan }}$}} & \multirow{3}{*}{$\begin{array}{c}\text { Presentassi } \\
\text { Kebechasilan }\end{array}$} & \multirow{2}{*}{\multicolumn{3}{|c|}{$\frac{\text { Pinkloise 65.0d8 }}{\text { Pengyjilian }}$}} & \multirow{3}{*}{$\begin{array}{c}\text { Presentabsi } \\
\text { Kebechasilan }\end{array}$} & \multirow{2}{*}{\multicolumn{3}{|c|}{$\frac{\text { Pink Noise:70.0dB }}{\text { Pengyjian }}$}} & \multirow{3}{*}{$\begin{array}{c}\text { Presentasi } \\
\text { Keberhasil } \\
\text { in }\end{array}$} \\
\hline & & & & & & & & & & & & & & & & & & & & \\
\hline & & & & & 1 & 2 & 3 & & 1 & 2 & 3 & & 1 & 2 & 3 & & 1 & 2 & 3 & \\
\hline Hilda & 1 & 1 & 1 & $100 \%$ & 1 & 1 & 1 & $100 \%$ & 1 & 1 & 1 & $100 \%$ & 0 & 0 & 0 & $0 \%$ & 0 & 0 & 0 & $0 \%$ \\
\hline litsan & 1 & 1 & 1 & $100 \%$ & 1 & 1 & 1 & $100 \%$ & 1 & 1 & 1 & $100 \%$ & 1 & 0 & 0 & $33,3 \%$ & 0 & 0 & 0 & $0 \%$ \\
\hline Fadel & 1 & 1 & 1 & $100 \%$ & 1 & 1 & 1 & $100 \%$ & 1 & 1 & 1 & $100 \%$ & 0 & 0 & 0 & $0 \%$ & 0 & 0 & 0 & OW \\
\hline Adel & 1 & 1 & 1 & $100 \%$ & 1 & 1 & 1 & $100 \%$ & 1 & 1 & 0 & $667,7 \%$ & 0 & 0 & 0 & $0 \%$ & 0 & 0 & 0 & $0 \%$ \\
\hline Arran & 1 & 1 & 1 & $100 \%$ & 1 & 1 & 1 & $100 \%$ & 1 & 0 & 0 & $33,3 \%$ & 0 & 0 & 0 & $0 \%$ & 0 & 0 & 0 & OW \\
\hline Tith & 1 & 1 & 1 & $100 \%$ & 1 & 1 & 1 & $100 \%$ & 1 & 0 & 0 & $33,3 \%$ & 0 & 0 & 0 & $0 \%$ & 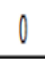 & 0 & 0 & $0 \%$ \\
\hline Angera & 1 & 1 & 1 & $100 \%$ & 1 & 1 & 1 & $100 \%$ & 0 & 1 & 1 & $66,7 \%$ & 1 & 0 & 0 & $33,3 \%$ & 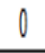 & 0 & 0 & Viv \\
\hline reto $\cdot$ & & & & $100 \%$ & & & & $100 \%$ & & chernas & & $71 \% \%$ & & cenernas & & $10 \%$ & & & & \\
\hline
\end{tabular}

Presentase rata-rata tingkat keberhasilan dari 7 data training yang terdapat pada tabel 4 adalah

- Untuk noise $50.0 \mathrm{~dB}$ rata-rata keberhasilan $=100 \%$

- Untuk noise $55.0 \mathrm{~dB}$ rata-rata keberhasilan $=100 \%$

- Untuk noise $60.0 \mathrm{~dB}$ rata-rata keberhasilan $=71 \%$

- Untuk noise $65.0 \mathrm{~dB}$ rata-rata keberhasilan $=10 \%$

- Untuk noise $70.0 \mathrm{~dB}$ rata-rata keberhasilan $=0 \%$

Dari presentase tersebut dapat diketahui bahwa dengan derau antara $50.0 \mathrm{~dB}$ hingga $60 \mathrm{~dB}$ suara pengguna masih dikenali oleh sistem dan pintu dapat terbuka. Namun untuk derau $70.0 \mathrm{~dB}$ suara pengguna tidak dikenali oleh sistem dan pintu tidak dapat terbuka. Maka secara keseluruhan alat atau sistem memiliki tingkat keberhasilan sebesar 56,2\% dalam mengenali suara pada data training jika terdapat derau dan pintu dapat terbuka.

Hasil pengujian terhadap data testing menggunakan derau pink noise pada modul elechouse v3 disajikan pada tabel 5 berikut :

Tabel 5. Pengujian Derau Terhadap Data Testing

\begin{tabular}{|c|c|c|c|c|c|c|c|c|c|c|c|c|c|c|c|c|c|c|c|}
\hline \multirow{4}{*}{$\begin{array}{l}\text { Suara } \\
\text { Pengeventa }\end{array}$} & \multirow{3}{*}{\multicolumn{2}{|c|}{\begin{tabular}{|c|} 
Pinallose:50.0008 \\
Pengy,jizn
\end{tabular}}} & \multirow{4}{*}{ Presentasi } & \multirow{3}{*}{\multicolumn{3}{|c|}{ 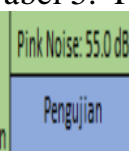 }} & \multirow{4}{*}{ 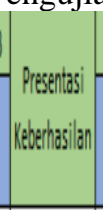 } & \multirow{3}{*}{\multicolumn{3}{|c|}{ 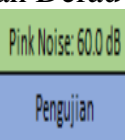 }} & \multirow{4}{*}{$\begin{array}{l}\text { Presentasi } \\
\text { reverhas ilan }\end{array}$} & \multirow{3}{*}{\multicolumn{3}{|c|}{$\frac{\text { Pink losice 650.0d8 }}{\text { Pengyi in }}$}} & & \multirow{2}{*}{\multicolumn{3}{|c|}{ Pinkloser: 7000d8 }} & \multirow{3}{*}{$\begin{array}{l}\text { Presentibsi } \\
\text { relechnsil }\end{array}$} \\
\hline & & & & & & & & & & & & & & & & & & & \\
\hline & & & & & & & & & & & & & & & & \multicolumn{3}{|c|}{ Pengyjitin } & \\
\hline & & 2 & & & & 3 & & & & 3 & & & & & & 1 & 2 & 3 & \\
\hline |smail & 0 & 0 & $0 \%$ & 0 & 0 & 0 & OW & 0 & 0 & 1 & 33,36 & 0 & 0 & 0 & OW & 0 & 0 & 0 & OW \\
\hline atho & 0 & 0 & $0 \%$ & 0 & 0 & 0 & OW & 0 & 0 & 0 & OW & 0 & 0 & 0 & OW & 0 & 0 & 0 & OW \\
\hline Qilla & 0 & 0 & OW & 0 & 0 & 0 & OW & 0 & 0 & 1 & 33,36 & 0 & 0 & 0 & OW & 0 & 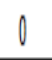 & 0 & OW \\
\hline Rizaddy & 0 & 0 & OW & 0 & 0 & 0 & OW & 0 & 0 & 0 & 0 & 0 & 0 & 0 & ON & 0 & 0 & 0 & O\% \\
\hline Riftoy & 0 & 0 & OW & 0 & 0 & 0 & OW & 0 & 0 & 0 & 0 & 0 & 0 & 0 & DW & 0 & 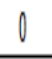 & 0 & OW \\
\hline Juna & 0 & 0 & OW & 0 & 0 & 0 & OW & 0 & 0 & 0 & 0 & 0 & 0 & 0 & OW & 0 & 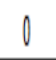 & 0 & OW \\
\hline Dinda & 0 & 0 & OW & 0 & 0 & 0 & OW & 0 & 0 & 0 & 0 & 0 & 0 & 0 & DW & 0 & 0 & 0 & OW \\
\hline $1018 \cdot 18$ & & & QW & toratede & akeber & & OW & & III & & $9,5 \%$ & & & & OW & & & & OW \\
\hline
\end{tabular}


JSAI : Journal Scientific and Applied Informatics

Vol. 4, No. 01, Januari 2021, hal. 116 125

E-ISSN: 2614-3054; P-ISSN: 2614-3062, accredited by Kemenristekdikti, Sinta 5

DOI: 10.36085

Presentase rata-rata tingkat keberhasilan dari 7 data testing yang terdapat pada tabel 5 adalah :

- Untuk noise $50.0 \mathrm{~dB}$ rata-rata keberhasilan $=0 \%$

- Untuk noise $55.0 \mathrm{~dB}$ rata-rata keberhasilan $=0 \%$

- Untuk noise $60.0 \mathrm{~dB}$ rata-rata keberhasilan $=9,5 \%$

- Untuk noise $65.0 \mathrm{~dB}$ rata-rata keberhasilan $=0 \%$

- Untuk noise $70.0 \mathrm{~dB}$ rata-rata keberhasilan $=0 \%$

Berdasarkan rata-rata presentase hasil pengujian tersebut maka secara keseluruhan alat atau sistem yang telah dibuat memiliki tingkat keberhasilan sebesar 1,9\% dalam mengenali suara pada data testing dan pintu dapat terbuka.

\subsection{Pengujian Jarak}

Pengujian dilakukan terhadap 14 dataset yang terbagi atas 7 data training yang tersimpan dalam 1 database suara dan 7 data testing. Pengujian dilakukan dengan ruangan tertutup. Pengukuran jarak dipilih secara random dengan kelipatan 30 . Hasil pengujian terhadap data training menggunakan jarak pada modul elechouse V3 disajikan pada tabel 6 berikut :

Tabel 6 Pengujian Pengukuran Jarak.Terhadap Data Training

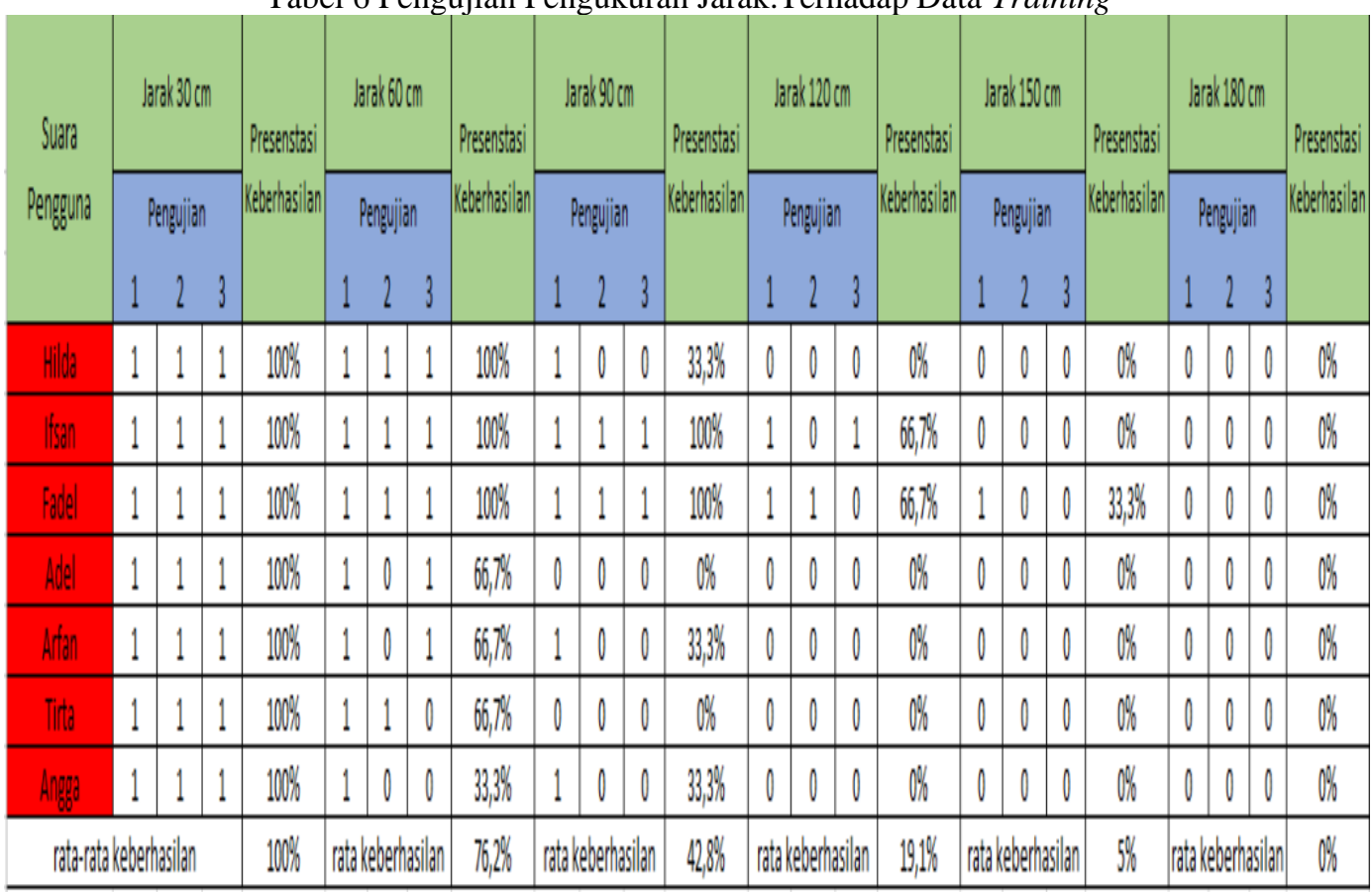

Presentase rata-rata tingkat keberhasilan dari 7 data training yang terdapat pada tabel 4.5 adalah:

- Untuk jarak $30 \mathrm{~cm}$ rata-rata keberhasilan $=100 \%$

- Untuk jarak $60 \mathrm{~cm}$ rata-rata keberhasilan $=76,2 \%$

- Untuk jarak $90 \mathrm{~cm}$ rata-rata keberhasilan $=42,8 \%$

- Untuk jarak $120 \mathrm{~cm}$ rata-rata keberhasilan $=19,1 \%$

- Untuk jarak $150 \mathrm{~cm}$ rata-rata keberhasilan $=5 \%$

- Untuk jarak $180 \mathrm{~cm}$ rata-rata keberhasilan $=0 \%$

Dari presentase tersebut dapat diketahui bahwa dengan jarak $30 \mathrm{~cm}$ hingga $120 \mathrm{~cm}$ suara pengguna masih dikenali oleh sistem dan pintu dapat terbuka. Namun untuk jarak $180 \mathrm{~cm}$ suara pengguna tidak dikenali oleh sistem dan pintu tidak dapat terbuka. Secara keseluruhan alat atau sistem memiliki tingkat keberhasilan sebesar $40,51 \%$ dalam mengenali suara pada data training jika terdapat jarak dan pintu dapat terbuka.

Hasil pengujian terhadap data testing menggunakan jarak pada modul elechouse v3 disajikan pada tabel 7 berikut : 
JSAI : Journal Scientific and Applied Informatics

Vol. 4, No. 01, Januari 2021, hal. 116 125

E-ISSN: 2614-3054; P-ISSN: 2614-3062, accredited by Kemenristekdikti, Sinta 5

DOI: 10.36085

Tabel 7. Pengujian Pengukuran Jarak Terhadap Data Testing

\begin{tabular}{|c|c|c|c|c|c|c|c|c|c|c|c|c|c|c|c|c|c|c|c|c|c|c|}
\hline \multirow{3}{*}{$\begin{array}{l}\text { Suarla } \\
\text { Penpeguna }\end{array}$} & \multicolumn{3}{|c|}{$\operatorname{lad} 630 \mathrm{~cm}$} & & \multirow{2}{*}{\multicolumn{2}{|c|}{ 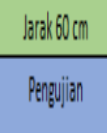 }} & \multirow{3}{*}{\multicolumn{2}{|c|}{ 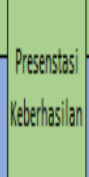 }} & \multicolumn{3}{|c|}{$\mid a d k 90 \mathrm{~cm}$} & & \multicolumn{2}{|c|}{ bad:1200m } & \multirow{3}{*}{ 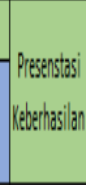 } & \multicolumn{3}{|c|}{$\operatorname{ladk} 1.150 \mathrm{~cm}$} & \multirow{3}{*}{ 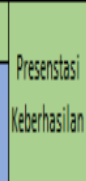 } & \multirow{2}{*}{\multicolumn{2}{|c|}{ 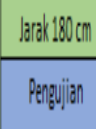 }} & \multirow{3}{*}{ 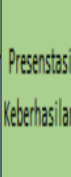 } \\
\hline & & ngy,an & & & & & & & & & & \multicolumn{2}{|c|}{ Pengyijin } & & \multicolumn{3}{|c|}{ Pengy, in } & & & & \\
\hline & & 2 & & & & & & & & 2 & & & & 23 & & & 2 & 3 & & & 23 & \\
\hline |smalal| & 0 & 0 & 0 & OW & 0 & & & $W^{N}$ & 0 & 0 & 0 & Do & 0 & $\begin{array}{lll}0 & 0\end{array}$ & Oh & 0 & 0 & 0 & OW & & \begin{tabular}{l|l}
0 & 0
\end{tabular} & OW \\
\hline ato & 0 & 0 & 0 & OW & 0 & & & OW & 0 & 0 & 0 & OW & 0 & \begin{tabular}{l|l}
0 & 0
\end{tabular} & 0.0 & 0 & 0 & 0 & OW & & \begin{tabular}{l|l}
0 & 0
\end{tabular} & $v_{w}$ \\
\hline Qila & 0 & 0 & 0 & OW & 0 & & & OW & 0 & 0 & 0 & OW & 0 & \begin{tabular}{l|l}
0 & 0
\end{tabular} & OW & 0 & 0 & 0 & OW & & 00 & 18 \\
\hline Rizaldy & 0 & 0 & 0 & DW & 0 & & & OW & 0 & 0 & 0 & OW & 0 & \begin{tabular}{l|l}
0 & 0
\end{tabular} & $N$ & 0 & 0 & 0 & OW & & \begin{tabular}{l|l}
0 & 0
\end{tabular} & \\
\hline Rifify & 0 & 0 & 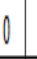 & OW & 0 & & & W & 0 & 0 & 0 & OW & 0 & 0 & OW & v & 0 & 0 & OW & & 00 & Ut \\
\hline Juna & 0 & 0 & 0 & OW & 0 & I & & OW & 0 & 0 & 0 & OW & 0 & 0 & OW & 0 & 0 & 0 & OW & & $\begin{array}{lll}0 & 0 \\
\end{array}$ & $x^{2}$ \\
\hline Dinda & 0 & 0 & 0 & OW & 0 & & & Wh & 0 & 0 & 0 & OW & 0 & 0 & 0.0 & 0 & 0 & 0 & OW & & 00 & 0.10 \\
\hline Iide-ret & & & & W & & & & W & & benthasil & & OW & & vehthail|: & W & & kevern' & & OW & & Wentha & OW \\
\hline
\end{tabular}

Presentase rata-rata tingkat keberhasilan dari 7 data testing yang terdapat pada tabel 4.6 adalah:

- Untuk jarak $30 \mathrm{~cm}$ rata-rata keberhasilan $=0 \%$

- Untuk jarak $60 \mathrm{~cm}$ rata-rata keberhasilan $=0 \%$

- Untuk jarak $90 \mathrm{~cm}$ rata-rata keberhasilan $=0 \%$

- Untuk jarak $120 \mathrm{~cm}$ rata-rata keberhasilan $=0 \%$

- Untuk jarak $150 \mathrm{~cm}$ rata-rata keberhasilan $=0 \%$

- Untuk jarak $180 \mathrm{~cm}$ rata-rata keberhasilan $=0 \%$

Berdasarkan rata-rata presentase hasil pengujian tersebut maka secara keseluruhan alat atau sistem yang telah dibuat memiliki tingkat keberhasilan sebesar $0 \%$ dalam mengenali suara pada data testing pada jarak $30 \mathrm{~cm}$ hingga $180 \mathrm{~cm}$.

\section{KESIMPULAN}

Berdasarkan penelitian yang telah dilakukan dapat disimpulkan bahwa rangkaian alat berupa mikrofon sebagai perekam suara, elechouse V3 sebagai voice recognition, Arduino sebagai mikrokontroler, relay sebagai saklar, serta solenoid lock door sebagai penggerak kunci otomatis pada pintu berhasil dirangkai, terintegrasi dengan baik dan dapat bekerja sesuai perancangan, sehingga otomatisasi sistem pengunci pintu telah berhasil dibuat. Sistem yang dibuat mampu membuka pintu secara otomatis dengan mendeteksi suara dan mencocokkan suara yang ada pada database, (suara yang telah dilatih dan tersimpan pada database). Hasil pengujian fungsionalitas menyatakan bahwa semua rangkaian alat berfungsi dan terintegrasi dengan baik. Hasil pengujian akurasi menggunakan variabel derau, non-derau dan jarak terhadap data testing dan data training terhadap pengguna berhak (data training) maupun tidak berhak (data testing) menunjukkan bahwa sistem yang dibangun memiliki tingkat akurasi yang baik sehingga sistem tersebut layak untuk diimplementasikan. Pengembangan sistem berikutnya diharapkan agar sistem dapat membedakan antara suara laki-laki dan perempuan.

\section{REFERENSI}

[1] C. A. Kadang et al., "Analisis Penyimpanan Data Biometrik Pada Basis Data," in Seminar Nasional Mahasiswa Ilmu Komputer dan Aplikasinya (SENAMIKA) Jakarta-Indonesia, 28 Januari 2020, 2020, pp. 163-171.

[2] H. Srikandi, Louise Dwi Kumala; Anggraeni; Busri, "Kata Tiruan ( Onomatope ) Tiruan Perbuatan Dalam Bahasa Mandarin,” Longda Xiokan J. Mandarin Learn. Teach., vol. 2, no. 2, pp. 79-85, 2019.

[3] A. Syamsudin; Ahmad Zaki, Zulfikar; Andiani, Linahtadiya; Ariyanti , Novi Dwi; Hikmah, Irmayatul; Widodo, Anatomi Suara, Kajian Fisika Medik, 2018th ed. Airlangga University Press, 2015.

[4] A. Mishra, A. Chhajed, and A. Gogne, "Voice Controlled Wheelchair With Obstacle Detection," Int. Res. J. Mod. Eng. Technol. Sci., vol. 02, no. 05, pp. 751-753, 2020. 
[5] M. Muralidharan, P. T. Jabir, and V. Pottakulath, "Voice Recognition Based Intelligent Wheelchair," Int. J. Innov. Res. Sci. Eng. Technol., vol. 5, no. 5, pp. 138-143, 2016.

[6] A. Rahayu, "Sistem Kendali Rumah Pintar Menggunakan Voice Recognition Module V3 Berbasis Mikrokontroler dan IOT," JTEV (JURNAL Tek. ELEKTRO DAN VOKASIONAL), vol. 06, no. 02, pp. 19-32, 2020.

[7] Faradiba, "Pengenalan Pola Sinyal Suara Manusia Menggunakan Metode Back Propagation Neural Network," J. EduMatSains, vol. 2, no. 1, pp. 1-16, 2017.

[8] C. Dinata, D. Puspitaningrum, P. Studi, T. Infomatika, and F. Teknik, "Implementasi Teknik Dynamic Time Warping ( Dtw ) Pada Aplikasi," J. Tek. Inform., vol. 10, no. 1, pp. 49-58, 2017, doi: 10.15408/jti.v10i1.6816.

[9] S. Ariyanti, S. S. Adi, and S. Purbawanto, "Sistem Buka Tutup Pintu Otomatis Berbasis Suara Manusia," ELINVO(Electronics, Informatics, Vocat. Educ., vol. 3, no. 1(May), pp. 83-91, 2018, doi: 10.21831/elinvo.v3i1.19076.

[10] P. N, Ashar Seppiawan; Nurussa'dah; Siwindarto, "Sistem Keamanan Pintu Pagar Otomatis Menggunakan Voice Recognition," J. Skripsi, pp. 1-6, 2017.

[11] A. F. S. M. M. B, A Asni; Rahman, "Rancang Bangun Buka Tutup Pintu Otomatis Menggunakan Pengenalan Isyarat Tutur," SNITT, pp. 251-255, 2017.

[12] C. Tristianto, "Penggunaan Metode Waterfall Untuk Pengembangan Sistem Monitoring Dan Evaluasi Pembangunan Pedesaan," J. Teknol. Inf. ESIT, vol. XII, no. 01 April, pp. 8-22, 2018, doi: 10.1093/nq/182.23.321-a.

[13] W. Nugraha and M. Syarif, "Penerapan Metode Prototype Dalam Perancangan Sistem Informasi Penghitungan Volume Dan Cost Penjualan Minuman Berbasis Website," JUSIM(Jurnal SItem Inf. Musiwaras), vol. 03, no. 02, Desember, pp. 97-105, 2018.

[14] T. Hidayat and M. Muttaqin, "Pengujian Sistem Informasi Pendaftaran dan Pembayaran Wisuda Online menggunakan Black Box Testing dengan Metode Equivalence Partitioning dan Boundary Value Analysis," J. Tek. Inform. UNIS JUTIS, vol. 6, no. 1, pp. 2252-5351, 2018, [Online]. Available: www.ccssenet.org/cis.

[15] E. Wirawan, Setia; Prasetyo, "Implementasi Metode Noise Gate, Low Pass Filter Dan Silent Removal Untuk Menghilangkan Noise Pada File Suara Menggunakan Parameter Dinamis," J. Teknol. Rekayasa, vol. 21, no. 3, pp. 152-162, 2016. 